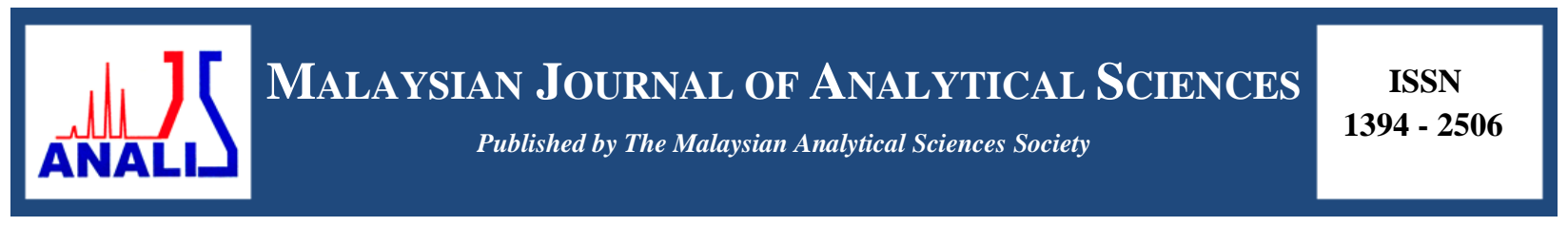

\title{
NUTRITIONAL COMPOSITION AND COLOUR ANALYSIS OF CHOLESTEROL-REDUCED EGG YOLK POWDER
}

\author{
(Komposisi Nutrisi dan Analisis Warna Serbuk Kuning Telur Rendah-Kolesterol) \\ Fauziah Che $\operatorname{In}^{1}$, Zaibunnisa Abdul Haiyee ${ }^{1 *}$, Osman Hassan ${ }^{2}$, Wan Aida Wan Mustapha ${ }^{2}$ \\ ${ }^{I}$ Faculty of Applied Sciences, \\ Universiti Teknologi MARA, 40450 Shah Alam, Selangor, Malaysia \\ ${ }^{2}$ School of Chemical Science and Food Technology, Faculty of Science and Technology, \\ Universiti Kebangsaan Malaysia, 43600 UKM Bangi, Selangor, Malaysia \\ *Corresponding author: nisha@salam.uitm.edu.my
}

Received: 24 February 2015; Accepted: 27 October 2015

\begin{abstract}
Dietary cholesterol should be limited to less than $200 \mathrm{mg} /$ day. A single large egg yolk contains approximately $275 \mathrm{mg}$ of cholesterol. Thus, consumption of a single egg yolk exceeds the recommended daily intake of cholesterol. This study was focused on determination of the effect of addition of increasing amount of $\beta$-cyclodextrin $(\beta-\mathrm{CD})$ to encapsulate cholesterol in egg yolk. The quality of cholesterol-reduced egg yolk powder was evaluated by determining its nutritional composition and colour analysis. Increasing amount of $\beta-C D(0-15 \mathrm{mM})$ was added in liquid egg yolk and the encapsulated cholesterol in the form of precipitate was removed. The supernatant was dried and the end product; cholesterol-reduced egg yolk powder (CREYP) was analyzed for moisture content, total lipid, fatty acids content, protein and colour. There were no significant difference $(\mathrm{p}>0.05)$ in term of total solid content. However, protein content of CREYP was significantly ( $\mathrm{p}<0.05)$ reduced up to $7 \mathrm{mM}$ $\beta-C D$ and no further significant reduction was noticed with further addition of $\beta$-cyclodextrin. The appearance of the powder became lighter in colour as validated using chromameter; $\mathrm{L}^{*}, \mathrm{a}^{*}, \mathrm{~b}^{*}, \mathrm{C}^{*}$ and $\mathrm{h}^{\mathrm{o}}$ values. The results obtained from this study indicate that cholesterol can be successfully removed from egg yolk. However, slight reduction in protein content was observed. Nutritional composition of CREYP was minimally affected with the removal of encapsulated cholesterol. Therefore, cholesterolreduced egg yolk powder can be utilized as an essential ingredient in any egg yolk based products.
\end{abstract}

Keywords: cholesterol, $\beta$-cyclodextrin, egg yolk, nutritional composition

\section{Abstrak}

Pengambilan kolesterol dalam diet seharusnya tidak melebihi $200 \mathrm{mg} / \mathrm{sehari}$. Sebiji kuning telur mengandungi hampir $275 \mathrm{mg}$ kolesterol. Maka, pengambilan sebiji kuning telur telah melebihi kadar cadangan diet seharian kolesterol. Kajian ini memfokuskan kepada kesan penambahan kuantiti $\beta$-siklodekstrin $(\beta-C D)$ untuk pengkapsulan kolesterol dalam kuning telur. Kualiti serbuk kuning telur kurang-kolesterol di analisis dengan menentukan komposisi nutrien dan analisis warna. Peningkatan kuantiti $\beta$-siklodekstrin $(\beta$-CD) $(0-15 \mathrm{mM})$ ditambahkan ke dalam kuning telur dan pengkapsulan kolesterol di dalam bentuk mendakan dibuang. Supernatan dikeringkan dan hasil produk (serbuk kuning telur kurang-kolesterol) yang terhasil dianalisa untuk jumlah kandungan kelembapan, jumlah lipid, asid lemak, protein dan warna. Tiada perbezaan yang signifikan ( $\mathrm{p}>0.05$ ) dalam jumlah kandungan pepejal. Walaubagaimanapun, kandungan protein kuning telur kurang-kolesterol berkurang secara signifikan $(\mathrm{p}<0.05)$ bagi penambahan $7 \mathrm{mM} \beta-\mathrm{CD}$ dan tiada pengurangan yang signifikan dengan peningkatan penambahan $\beta$-CD. Serbuk kuning telur menunjukkan pengurangan warna seperti dibuktikan menggunakan kromameter; bacaan $L^{*}, a^{*}, b^{*}$, $\mathrm{C}^{*}$ dan $\mathrm{h}^{\mathrm{o}}$. Keputusan menunjukkan bahawa kolesterol telah berjaya dibuang daripada kuning telur. Walaubagaimanapun, pengurangan sedikit kandungan protein diperhatikan. Kesan pengurangan pengkapsulan kolesterol ke atas komposisi nutrisi serbuk kuning telur kurang-kolesterol adalah sedikit. Maka, serbuk kuning telur kurang-kolesterol dapat digunakan sebagai bahan ramuan penting di dalam mana - mana produk berasaskan kuning telur. 


\section{Fauziah et al: NUTRITIONAL COMPOSITION AND COLOUR ANALYSIS OF CHOLESTEROL-REDUCED EGG YOLK POWDER}

Kata kunci: kolesterol, $\beta$-siklodekstrin, kuning telur, komposisi nutrisi

\section{Introduction}

Egg yolk contains approximately $50 \%$ of solids. The major constituents of the solid matter in egg yolk are lipids $(65-70 \%$ on dry basis) and proteins (30\% on dry basis), consisting of proteins in solution referred to as livetin, lipoprotein particles including high-density lipoproteins (HDLs), low-density lipoproteins (LDLs), and phosvitin [1]. Each constituent of yolk possesses special physical and chemical characteristics responsible for its own functional properties. Thus, yolk represents a major source of active principles usable in medical, pharmaceutical, cosmetic and biotechnological industries [2].

Nowadays foods not only intended to provide necessary nutrients, but also to prevent nutrition-related diseases and improve physical and mental well-being of the consumers [3]. It can be assumed that cholesterol-lowering and cholesterol-free products or those containing phystosterol esters, which are considered to lower the cholesterols level, will gain increasing relevance in the coming years [3]. Food companies have developed many methods to reduce cholesterol in food, such as short-path and vacuum molecular distillation, blending in vegetable oils, extraction by organic solvents, cholesterol degradation by cholesterol oxidases, and removal by supercritical carbon dioxide extractions. However, the cost of these are non-selective methods is high, and when cholesterol removed, flavor and nutritional components are removed as well [3, 4, 5]. This was agreed by Heshmati and Khodadadi, [6] where these methods are not applicable to all edible products. For example, cis fatty acid isomers are converted to atherogenic trans isomers during vacuum steam distillation method, aromatic and carcinogenic solvents may remain in the food after utilization, and a substantial capital investment and operating costs are required for carbon dioxide extraction procedure [7]. Moreover, the usage of solvents may present health risk or are so harsh that the restoration of the egg texture is impossible [8]. Vegetable oil extraction processes able to achieve substantial removal of cholesterol however, the amount of fresh oil needed for cholesterol extraction, usually $4-25$ (wt/wt) times more than the egg yolk makes such processes impractical and uneconomical because after extraction such oil must be discarded [8]. Even though there is an improvement in the recyclability of the oil used, still the amount of oil used is in huge amount.

Encapsulation using cyclodextrins (CDs) is a method that has been used during the last few years in the cosmetics, drug and food industries for many purposes. Their molecular structure and shape made CDs to have the ability to act as molecular containers by entrapping guest molecules in their internal cavity [3]. Cyclodextrin can bind to various kinds of low molecule compounds into its cave structure, thereby stabilising the low molecule organic compounds by the inclusion effect [9]. The hydrophobic cavity forms inclusion complexes with a wide range of guest molecules. Non-covalent bonds are formed or broken during the complex formation and in aqueous solution, the complexes readily dissociate remaining the released molecules in equilibrium with the molecules bound within CD cavity [3]. The internal cavity which is hydrophobic allows the cyclodextrins to complex molecules such as aromatic alcohols, fatty acids and their esters and cholesterol.

Fresh eggs in liquid form are also difficult to transport because of their bulkiness, fragility, and highly perishable nature [10]. Therefore egg in powder form, able to overcome this problem. This study is therefore aimed at determining the effects of addition of $\beta$-cyclodextrin on the nutritional composition of cholesterol-reduced egg yolk powder dried using oven drying.

\section{Materials}

\section{Materials and Methods}

Fresh eggs were purchased from local market in Shah Alam, Malaysia. $\beta$-CD (purity 99.5\%) was purchased from the Sigma Chemical Company (St. Louis, MO, USA). Chloroform-absolute alcohol, hexane (Ph. Eur., GC grade, Merck, Germany) and ethanol (Ph. Eur., Merck, Germany) were used in this study. Purified water (Milli QUV plus water system, Millipore, Molsheim, France) was also been used. 


\section{Preparation of cholesterol-reduced egg yolk: Formation of inclusion complex}

Cholesterol was removed from egg yolk by formation of egg yolk cholesterol: $\beta$-cyclodextrin inclusion complex (EYCBIC) following the method used by Awad et al. [11] with some modifications. The egg yolk $\mathrm{pH}$ and ${ }^{\circ} \mathrm{Brix}$ were adjusted to 10.5 and 2.9, respectively with continuous stirring using homogenizer (IKA Ultra Turrax T25 Homogenizer, UK) at $210 \pm 10 \mathrm{rpm}$. The egg yolk was placed in a laboratory shaking water bath (100 rpm, 1 hour, $\left.50{ }^{\circ} \mathrm{C}\right)$. Diluted egg yolk $(5 \mathrm{~g})$ was mixed with increasing amounts of $\beta-\mathrm{CD}(0-15 \mathrm{mM})$ with continuous mixing using a vortex mixer (Laboratory equipment, VELP, Italy) at $1600 \mathrm{rpm}$ for 10 minutes. The treated egg yolk was placed in a shaking water bath $\left(100 \mathrm{rpm}, 20 \mathrm{~min}, 50{ }^{\circ} \mathrm{C}\right)$ and cooled to $8-10^{\circ} \mathrm{C}$ for 1 hour and centrifuged at $5000 \mathrm{rpm}$ at $5{ }^{\circ} \mathrm{C}$ for $15 \mathrm{~min}$ (Hettich Universal 320, Benchtop centrifuge, Germany). Insoluble $\beta$-CD-cholesterol inclusion complex in the form of sediment was separated from the supernatant. The $\mathrm{pH}$ of the supernatant was adjusted back to $\mathrm{pH}$ 6.0. The supernatant were oven dried $\left(44^{\circ} \mathrm{C}, 4\right.$ hours) for production of cholesterol-reduced egg yolk powder.

\section{Compositional analysis}

\section{Moisture content}

The moisture content of the samples were determined in triplicate by drying under vacuum oven at $98-100{ }^{\circ} \mathrm{C}$ according to the method as described by AOAC, 1975 [12].

\section{Total lipid}

Lipids were extracted from the egg yolks using the standard method [13]. According to this method, approximately $4 \mathrm{~g}$ well mixed egg yolk was weighed into a $100 \mathrm{~mL}$ volumetric flask and $25 \mathrm{~mL}$ chloroform-absolute alcohol were added (1:1) the solvent was mixed very slowly from pipette. It was shaken constantly until proteins were coagulated. An additional $60-65 \mathrm{~mL}$ mixed solvent was added and let stand for 1 hour, shaken every $5 \mathrm{~min}$. At the end of the time it was diluted to volume with mixed solvent and the mixture was let stand until clear. The mixture was then filtered very slowly (filtrate should be clear), solvent was evaporated and egg yolk lipid was obtained. The total lipid content of the samples was evaluated in triplicate.

\section{Cholesterol determination}

The supernatant $(1 \mathrm{~mL})$ were placed in screw-capped glass tubes $(15 \times 180 \mathrm{~mm})$. The samples were saponified [14]. The extracts were redissolved in $1 \mathrm{~mL}$ of hexane and stored at $-20{ }^{\circ} \mathrm{C}$ until analysis. The total cholesterol was determined using gas chromatography [15]. The percentage of cholesterol reduction was calculated using the equation given below:

(amount of cholesterol at $0 \mathrm{mM}$ - amount of cholesterol at $15 \mathrm{mM}$ ) x 100

Cholesterol reduction $=$

(\%) at $15 \mathrm{mM}$ (amount of cholesterol at $0 \mathrm{mM}$ - amount of cholesterol at $15 \mathrm{mM}$ ) $\times 100$

amount of cholesterol at $0 \mathrm{mM}$

\section{Fatty acids determination}

FAMEs were prepared according to the method as described by Zara et al. [16] with some modifications. FAME analysed were performed on gas chromatograph (Perkin Elmer). Fatty acid methyl esters were separated on a capillary column (HP-5 MS; Agilent $0.25 \mathrm{~mm}$ x $30 \mathrm{~m} 0.25 \mu \mathrm{m}$ ) equipped with an auto-sampler. The initial temperature of $50{ }^{\circ} \mathrm{C}$ was held for $3 \mathrm{~min}$, increased to $180{ }^{\circ} \mathrm{C}$ at $10{ }^{\circ} \mathrm{C} \mathrm{min}$, increased to $220{ }^{\circ} \mathrm{C}$ at $5{ }^{\circ} \mathrm{C} / \mathrm{min}$ and held for $10 \mathrm{~min}$. The column temperature was elevated to $230^{\circ} \mathrm{C}$ at $5{ }^{\circ} \mathrm{C} / \mathrm{min}$ and held at the final temperature for 3 min. Helium was used as the carrier gas at a flow rate of $3.0 \mathrm{~mL} / \mathrm{min}$. The detector was set at $240{ }^{\circ} \mathrm{C}$. Fatty acid methyl esters were identified by comparison with retention times of standard mixture. The fatty acid content of egg yolk was calculated using the following formula equation $2[17,18]$ :

$$
\text { Concentration }(\mathrm{mg} / \mathrm{g})=
$$

Peak area of a given fatty acid $\times$ concentration of IS $(\mathrm{mg} / \mathrm{mL})$ peak area of IS

Weight of sample (g)

IS is defined as internal standard. 


\section{Protein determination}

The Kjeldahl method of nitrogen analysis was conducted to calculate the protein content [13]. The protein content of liquid egg yolk treated from $0-15 \mathrm{mM}$ addition of $\beta$-CD was determined in triplicate.

\section{Colour determination}

Colour values $\left(L^{*}, a^{*}, b^{*}, C^{*}, h^{o}\right)$ of EY powder treated from treatment of liquid egg yolk with $0-15 \mathrm{mM}$ addition of $\beta$-CD were measured in triplicate using Chromameter CR-400.

\section{Statistical analysis}

Mean values from the three separate experiments or replicate analysis were reported. The statistical significance of observed differences among three treatment means evaluated by analysis of variance (ANOVA) and the comparison of means were carried out by Duncan's multiple range test $(\mathrm{p}<0.05)$ by using SPSS 10 for Windows.

\section{Moisture content}

\section{Results and Discussion}

Moisture content is important in food quality and preservation. Moisture content is expressed as dry basis. Dry basis of moisture content is defined as the ratio of water weight to the dried weight of sample [19]. The moisture content of the egg yolk powder with the addition of increasing amount of $\beta$-cyclodextrin was shown in Table 1 . Moisture content of the dried egg yolk powder obtained in this study was in the range of $2.4-2.7 \%$. Previous researcher suggested the optimum moisture content for egg yolk powder should be within the range of $2-4 \%$, low enough to extend the shelf life in an environment of low humidity [10].

Table 1. Moisture content of cholesterol-reduced egg yolk powder

\begin{tabular}{lcccccccc}
\hline Concentration of $\beta$-cyclodexrin $(\mathbf{m M})$ & $\mathbf{0}$ & $\mathbf{1}$ & $\mathbf{3}$ & $\mathbf{5}$ & $\mathbf{7}$ & $\mathbf{1 1}$ & $\mathbf{1 3}$ & $\mathbf{1 5}$ \\
\hline \multirow{2}{*}{ Moisture content $(\mathrm{g} / 100 \mathrm{~g}$ egg yolk powder) } & $2.5 \pm$ & $2.4 \pm$ & $2.6 \pm$ & $2.4 \pm$ & $2.6 \pm$ & $2.5 \pm$ & $2.7 \pm$ & $2.7 \pm$ \\
& $0.66^{\mathrm{a}}$ & $0.35^{\mathrm{a}}$ & $0.48^{\mathrm{a}}$ & $0.35^{\mathrm{a}}$ & $0.11^{\mathrm{a}}$ & $0.09^{\mathrm{a}}$ & $0.11^{\mathrm{a}}$ & $0.10^{\mathrm{a}}$ \\
\hline
\end{tabular}

Means within the same row with different letters differ significantly $(\mathrm{p}<0.05)$.

\section{Total lipid}

The lipid content in egg yolk are principally triglycerides $(65 \%, \mathrm{w} / \mathrm{w})$, phospholipids $(28 \%, \mathrm{w} / \mathrm{w})$, cholesterol (5 $\%$, w/w) [20] and were exclusively associated with lipoproteins assemblies [21]. The concentration of lipid in the dried cholesterol-reduced egg yolk powder showed in Figure 1. The reduction of total lipid was from 55 to 48 $\mathrm{g} / 100 \mathrm{gm}$ egg yolk powder. Our previous work has shown and proven that certain fraction of cholesterol molecules was included into $\beta-C D$ cavity which confirmed the formation of inclusion complex and finally in accomplishment of the reduction of cholesterol in egg yolk [22]. Since cholesterol molecules are part of egg yolk lipids, the total lipid contents of egg yolk powder were expected to be slightly reduced. There were no significant differences $(p>0.05)$ in total lipid content as increased in the addition of $\beta-C D$ concentration.

The reduction of total lipids should be due to removal cholesterol through encapsulation. Egg yolk consists mainly of $68 \%$ low-density lipoproteins (LDL), $16 \%$ high-density lipoproteins (HDL), $10 \%$ livetins and $4 \%$ phosvitins [23]. Cholesterols which were situated in the large spherical of LDL particles, probably the reason why total lipids were reduced along with cholesterol extraction.

The cholesterol removal process such as stirring, separation and centrifugation during separation of cholesterol: $\beta$ $\mathrm{CD}$ inclusion complexes may affect the decreasing of total lipid content of egg yolk. These results correlated with the study by Kim et al. [24]. Furthermore, Ha et al. [25] suggested that the free fatty acids in food may be reduced because they are trapped in $\beta-\mathrm{CD}$ cavities molecule. 


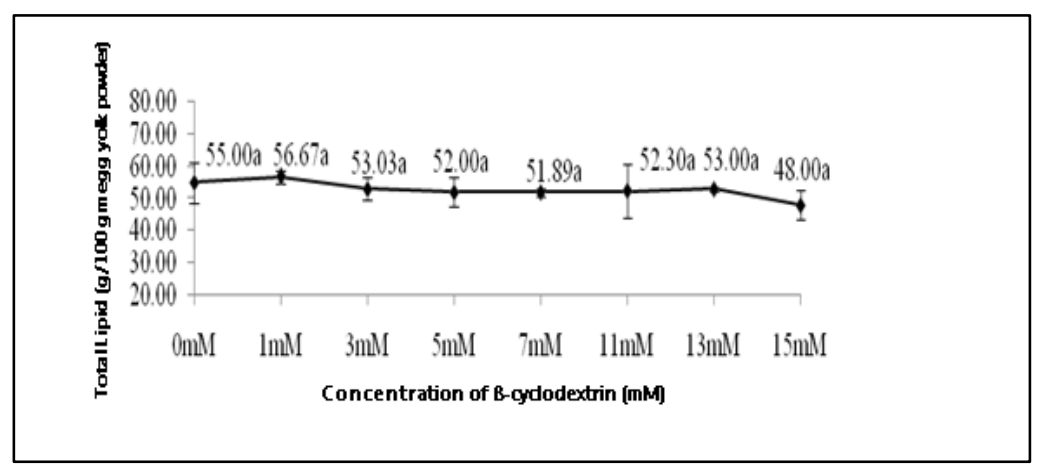

Figure 1. Total lipid content of cholesterol-reduced egg yolk powder

\section{Cholesterol reduction}

Increasing amounts of $\beta$-cyclodextrin ( $\beta$-CD) were added to optimize the weight ratio for maximal cholesterol removal from the egg yolk. The concentrations of cholesterol remaining in the supernatant after removal of the pellet inclusion complexes were shown in Figure 2. The curve shows a gradual decrease in the concentration of cholesterol in the egg yolk as the concentration of added $\beta-\mathrm{CD}(\mathrm{mM})$ increased, which is in agreement with the findings of the previous study [26]. At $0 \mathrm{mM} \beta-\mathrm{CD}$, cholesterol content was $12.51 \mathrm{mg} / \mathrm{gm}$, whereas as $1 \mathrm{mM}, 3 \mathrm{mM}$, $5 \mathrm{mM}, 7 \mathrm{mM}, 11 \mathrm{mM}$ and $13 \mathrm{mM} \beta-\mathrm{CD}$ were recorded at 10.72, 6.14, 4.36, 3.87, 2.02 and $1.14 \mathrm{mg} / \mathrm{gm}$ cholesterol content respectively. Cholesterol-reduced egg yolk powder at $15 \mathrm{mM} \beta-\mathrm{CD}$ was lower than at $0 \mathrm{mM} \beta-\mathrm{CD}$ $(\mathrm{p}<0.05)$. At $15 \mathrm{mM} \beta-\mathrm{CD}$ with $0.24 \mathrm{mg} / \mathrm{gm}$ cholesterol content left resulted in $98 \%$ cholesterol was extracted from the $5 \mathrm{gm}$ supernatant.

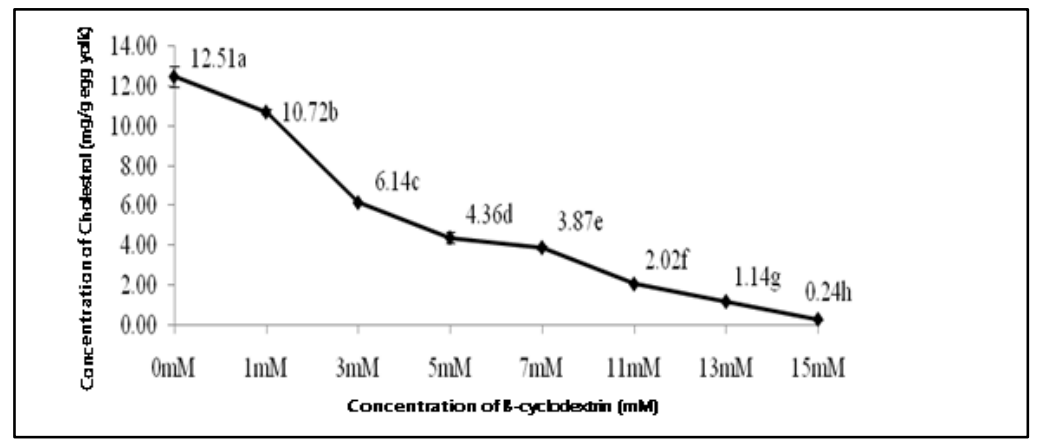

Figure 2. Cholesterol contents of cholesterol-reduced egg yolk powder. Data are expressed as means \pm SD. Value with different letters indicates significant difference at $\mathrm{p}<0.05$.

\section{Fatty acids determination}

Fatty acids were prepared from different concentration of increasing $\beta$-CD concentrations according to the method as described by Zara et al. [16]. Among the different fatty acids tested (Table 2), there were no difference ( $p>0.05)$ was observed as increasing $\beta$-CD concentrations for linolenic acid (C18:3) with $0.86 \pm 0.13^{\mathrm{a}}, 0.56 \pm 0.34^{\mathrm{a}}, 0.56 \pm$ $0.46^{\mathrm{a}}, 0.30 \pm 0.10^{\mathrm{a}}$ and $0.48 \pm 0.04^{\mathrm{a}}$ (mg/g fatty acids) for $0 \mathrm{mM}$ (control), $3 \mathrm{mM}, 7 \mathrm{mM}, 11 \mathrm{mM}$ and $15 \mathrm{mM} \beta-\mathrm{CD}$ concentrations respectively (Table 2). Arachidonic acid (C20:4 (n-6)) showed significant different with the highest $\beta$-CD concentrations $(15 \mathrm{mM})$, with fatty acids content of $5.51 \pm 0.03^{\mathrm{a}}, 5.39 \pm 0.07^{\mathrm{a}}, 5.69 \pm 0.09^{\mathrm{a}}, 5.42 \pm 0.14^{\mathrm{a}}$ and $1.67 \pm 0.33^{\mathrm{b}}$ for $0 \mathrm{mM}$ (control), $3 \mathrm{mM}, 7 \mathrm{mM}, 11 \mathrm{mM}$ and $15 \mathrm{mM} \beta$-CD concentrations respectively. 
Table 2. Fatty acids content of cholesterol-reduced egg yolk powder

\begin{tabular}{lccccc}
\hline \multirow{2}{*}{ Fatty acids } & $\mathbf{5}$ & \multicolumn{5}{c}{ Concentration $\beta-C D(\mathbf{m M})$} \\
\cline { 2 - 6 } & $\mathbf{0}$ & $\mathbf{3}$ & $\mathbf{7}$ & $\mathbf{1 1}$ & $\mathbf{1 5}$ \\
\hline Myristic acid C14:0 & $2.02 \pm 0.14^{\mathrm{a}}$ & $1.90 \pm 0.01^{\mathrm{ab}}$ & $1.81 \pm 0.08^{\mathrm{bc}}$ & $1.69 \pm 0.03^{\mathrm{c}}$ & $1.45 \pm 0.03^{\mathrm{d}}$ \\
Palmitoleic acid C16:1 & $22.42 \pm 2.87^{\mathrm{a}}$ & $24.81 \pm 0.51^{\mathrm{a}}$ & $16.56 \pm 1.89^{\mathrm{b}}$ & $22.45 \pm 0.93^{\mathrm{a}}$ & $20.12 \pm 1.57^{\mathrm{b}}$ \\
Palmitic acid C16:0 & $118.92 \pm 8.40^{\mathrm{b}}$ & $133.16 \pm 0.72^{\mathrm{a}}$ & $118.68 \pm 2.04^{\mathrm{b}}$ & $105.27 \pm 4.35^{\mathrm{c}}$ & $48.09 \pm 0.62^{\mathrm{d}}$ \\
Linolenic acid (C18:3) & $0.86 \pm 0.13^{\mathrm{a}}$ & $0.56 \pm 0.34^{\mathrm{a}}$ & $0.56 \pm 0.46^{\mathrm{a}}$ & $0.30 \pm 0.10^{\mathrm{a}}$ & $0.48 \pm 0.04^{\mathrm{a}}$ \\
Oleic acid C18:1 (n-9) & $217.8 \pm 3.89^{\mathrm{a}}$ & $220.62 \pm 1.88^{\mathrm{a}}$ & $222 \pm 1.41^{\mathrm{a}}$ & $186.11 \pm 5.81^{\mathrm{b}}$ & $69.97 \pm 1.03^{\mathrm{c}}$ \\
Linoleic acid C18:2(n-6) & $20.1 \pm 0.04^{\mathrm{ab}}$ & $18.77 \pm 0.40^{\mathrm{b}}$ & $24.31 \pm 1.71^{\mathrm{a}}$ & $18.2 \pm 3.59^{\mathrm{b}}$ & $18.38 \pm 0.20^{\mathrm{b}}$ \\
Stearic acid C18:0 & $33.84 \pm 2.17^{\mathrm{a}}$ & $33.79 \pm 0.63^{\mathrm{a}}$ & $35.16 \pm 0.69^{\mathrm{a}}$ & $35.02 \pm 0.67^{\mathrm{a}}$ & $12.08 \pm 0.04^{\mathrm{b}}$ \\
Arachidonic acid & & & & & \\
C20:4 (n-6) & & & & \\
EPA C20:5(n-3) & $1.07 \pm 0.04^{\mathrm{b}}$ & $1.21 \pm 0.04^{\mathrm{a}}$ & $1.14 \pm 0.04^{\mathrm{ab}}$ & $0.45 \pm 0.05^{\mathrm{c}}$ & $0 \pm 0.00^{\mathrm{d}}$ \\
DHA C22:6 (n-3) & $1.48 \pm 0.16^{\mathrm{ab}}$ & $1.71 \pm 0.03^{\mathrm{a}}$ & $1.30 \pm 0.02^{\mathrm{ab}}$ & $0.68 \pm 0.68^{\mathrm{bc}}$ & $0.21 \pm 0.10^{\mathrm{c}}$ \\
\hline
\end{tabular}

Means within the same row with different letters differ significantly $(\mathrm{p}<0.05)$.

Whereas for $15 \mathrm{mM} \beta-\mathrm{CD}$ concentration, there was totally lost in EPA as $0 \mathrm{mM}$ (control) having lower EPA content. However, other fatty acids; myristic acid (C14:0), palmitoleic acid (C16:1), palmitic acid (C16:0), oleic acid (C18:1 (n-9)), linoleic acid (C18:2 (n-6)), EPA (C20:5 (n-3)), and DHA (C22:6 (n-3)) resulted in difference in decreasing of fatty acids content $(\mathrm{p}<0.05)$ as increasing $\beta-\mathrm{CD}$ concentrations. These results were same as reported by Awad et al. [27]. The changes in concentration of C18:1 (n-9), C18:2 (n-6) and C16:0 might be due to changes in the relatively concentrations of triglycerides and phospholipids, which are composed of different fatty acids [27]. The major fatty acids of triglycerides are oleic acids and palmitic acid. Therefore as the $\beta$-CD concentrations were increased, all the fatty acids of the egg yolk powder being tested were decreased.

\section{Protein quantification}

The egg yolk protein content was significantly decreased $(\mathrm{p}<0.05)$ as cholesterol being reduced with increasing $\beta$ $\mathrm{CD}$ concentrations from 0 to $15 \mathrm{mM}$ (Figure 3 ). Protein content in the egg yolk was significantly reduced as $\beta-\mathrm{CD}$ concentration increased up to $7 \mathrm{mM}$. There was no significant difference with further addition of $\beta$-CD. Smith et al. [28] reported that protein reduction of $9.2 \%$ with $89.2 \%$ cholesterol reduction in liquid egg yolk using $\beta$-CD which proven better reduction of cholesterol with $98 \%$ reduction of cholesterol with almost less than $9 \%$ protein reduction in this study.

Cyclodextrins molecular structure is unique with hydrophilic exterior properties and hydrophobic in central of its cavities. These properties allow them to form non-covalent inclusion complexes by encapsulating of variety of 'guest' molecules into the 'host' which refer to their central cavities through associate and dissociating process. Kim et al. [24] and Kwak et al. [30] reported the protein reduction in milk after removal of cholesterol. It was confirmed that the protein content of cream was reduced during reduction of cholesterol by $4-10 \% \beta$-CD due to entrapment of amino acids in $\beta$-CD cavities [29].

Maskooki et al. [31] reported that, the outer surface of $\beta$-CD macromolecules has affinity to absorb the negative charges that cover the protein surfaces. Subsequently, parts of protein together with $\beta$-CD:cholesterol inclusion complexes leave during centrifugation and separation process. Thus, cholesterol reduction processing such as mixing, separation, and centrifugation may affect decrease of total protein content of egg yolk. 


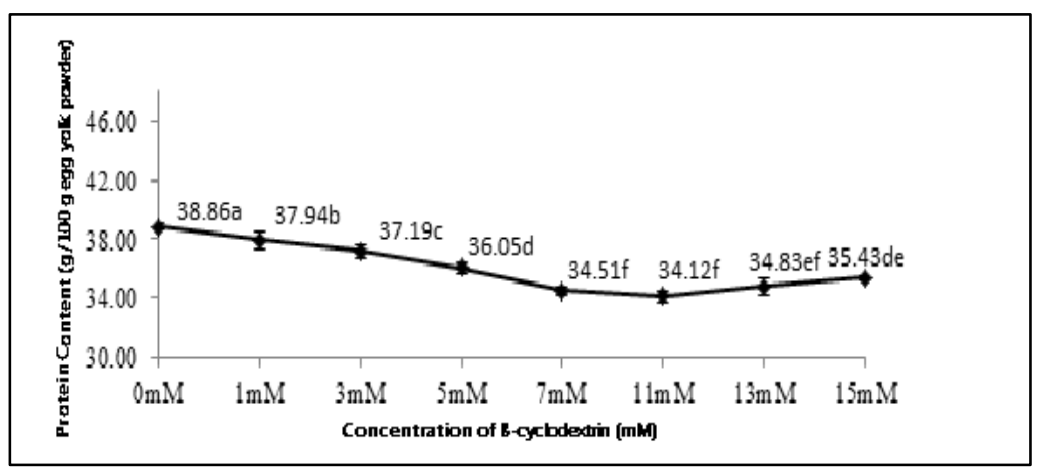

Figure 3. Protein contents of cholesterol-reduced egg yolk powder

\section{Colour determination}

The colour analysis of the egg yolk powder produced from the reduction of cholesterol by $\beta$-CD: cholesterol inclusion complexes was confirmed by the data obtained (Table 3) from the instrumental analysis using Minolta Chroma Meter CR-300 (Japan) to detect the lightness $\left(\mathrm{L}^{*}\right)$, redness $\left(\mathrm{a}^{*}\right)$ and yellowness $\left(\mathrm{b}^{*}\right)$, saturation, $\left(\mathrm{C}^{*}\right)$ and hue angle $\left(\mathrm{h}^{\circ}\right)$ values of egg yolk powder. $\mathrm{L}^{*}$ value represents lightness (negative towards black, positive towards white), $a^{*}$ value is the red-greenness colour scale (negative towards green, positive towards red) whereas $b^{*}$ value represents blue-yellow colour scale (negative towards blue, positive towards yellow).

The lightness $\left(\mathrm{L}^{*}\right)$, redness $\left(\mathrm{a}^{*}\right)$ and yellowness $\left(\mathrm{b}^{*}\right)$, Chroma $\left(\mathrm{C}^{*}\right)$ and hue angle $\left(\mathrm{h}^{\circ}\right)$ of egg yolk powder were significantly different with direct correlation with increasing addition amount of $\beta$-CD concentrations as cholesterol being reduced.

Table 3. Colour values of cholesterol-reduced egg yolk powder

\begin{tabular}{lccccc}
\hline Egg yolk powder & ${ }^{\mathrm{L}}$ & $\mathbf{a}^{*}$ & $\mathbf{b}^{*}$ & $\mathbf{C}^{*}$ & $\mathbf{h}^{\mathbf{o}}$ \\
\hline $0 \mathrm{mM}$ & $72.55 \pm 0.03^{\mathrm{h}}$ & $1.83 \pm 0.09^{\mathrm{a}}$ & $39.40 \pm 0.07^{\mathrm{a}}$ & $39.42 \pm 0.07^{\mathrm{a}}$ & $87.57 \pm 0.18^{\mathrm{f}}$ \\
$1 \mathrm{mM}$ & $73.06 \pm 0.06^{\mathrm{g}}$ & $1.48 \pm 0.13^{\mathrm{a}}$ & $38.49 \pm 0.04^{\mathrm{b}}$ & $38.50 \pm 0.03^{\mathrm{b}}$ & $87.88 \pm 0.04^{\mathrm{e}}$ \\
$3 \mathrm{mM}$ & $73.70 \pm 0.15^{\mathrm{f}}$ & $1.29 \pm 0.07^{\mathrm{c}}$ & $36.57 \pm 0.04^{\mathrm{c}}$ & $36.25 \pm 0.22^{\mathrm{c}}$ & $88.09 \pm 0.11^{\mathrm{de}}$ \\
$5 \mathrm{mM}$ & $74.34 \pm 0.29^{\mathrm{e}}$ & $1.08 \pm 0.03^{\mathrm{de}}$ & $34.62 \pm 0.06^{\mathrm{d}}$ & $34.57 \pm 0.20^{\mathrm{d}}$ & $88.24 \pm 0.14^{\mathrm{d}}$ \\
$7 \mathrm{mM}$ & $79.53 \pm 0.10^{\mathrm{d}}$ & $1.13 \pm 0.16^{\mathrm{cd}}$ & $33.37 \pm 0.15^{\mathrm{e}}$ & $33.41 \pm 0.19^{\mathrm{e}}$ & $89.74 \pm 0.02^{\mathrm{c}}$ \\
$11 \mathrm{mM}$ & $80.68 \pm 0.19^{\mathrm{c}}$ & $0.95 \pm 0.14^{\mathrm{ef}}$ & $32.69 \pm 0.21^{\mathrm{f}}$ & $31.57 \pm 0.14^{\mathrm{f}}$ & $89.80 \pm 0.14^{\mathrm{c}}$ \\
$13 \mathrm{mM}$ & $82.47 \pm 0.15^{\mathrm{b}}$ & $0.86 \pm 0.08^{\mathrm{f}}$ & $31.70 \pm 0.07^{\mathrm{g}}$ & $30.71 \pm 0.15^{\mathrm{g}}$ & $90.03 \pm 0.03^{\mathrm{b}}$ \\
$15 \mathrm{mM}$ & $83.74 \pm 0.12^{\mathrm{a}}$ & $0.43 \pm 0.41^{\mathrm{g}}$ & $28.42 \pm 0.07^{\mathrm{h}}$ & $28.11 \pm 0.03^{\mathrm{h}}$ & $92.03 \pm 0.19^{\mathrm{a}}$ \\
\hline
\end{tabular}

Means within a column with different letters differ significantly $(\mathrm{p}<0.05)$.

Increasing amount of $\beta$-CD concentrations resulted in production of egg yolk powder with reduced in yellow colour. This was proven as the L-values of egg yolk powder was increased showing that the egg yolk powder turn to much lighter colour. Decreasing of redness $\left(\mathrm{a}^{*}\right)$ and yellowness $\left(\mathrm{b}^{*}\right)$ intensity colour of egg yolk powder correlate with reduction of yellowness of yolk and finally makes the egg yolk powder became greener and bluer as increased in the addition of $\beta$-CD. The colour of egg yolk is attributed to fat-soluble carotenoids (xanthophylls; including lutein, zeaxanthin, $\beta$-cryptoxanthin and minor amounts $\beta$-carotene) [32]. It appeared that the lightness $\left(\mathrm{L}^{*}\right)$, redness $\left(\mathrm{a}^{*}\right)$ and yellowness $\left(b^{*}\right)$, were influenced by $\beta$-CD concentrations additions with the reduction of cholesterol. Lipidsoluble pigments of egg yolk probably were being trapped by $\beta-C D$ cavities during the cholesterol removal process. 
Chroma $\left(\mathrm{C}^{*}\right)$ is a measure of intensity or saturation and calculated as $\left[\left(\mathrm{a}^{*}\right)^{2}+\left(\mathrm{b}^{*}\right)^{2}\right]^{1 / 2}$ and represents saturation

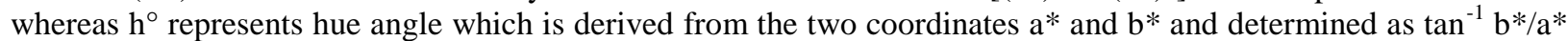
[33]. Hue angle $\left(\mathrm{h}^{\circ}\right)$ is expressed on a $360^{\circ}$ grid where $0^{\circ}=$ bluish-red, $90^{\circ}=$ yellow, $180^{\circ}=$ green and $270^{\circ}=$ blue [34]. Egg yolk powder with yellow coloured sample going from thick yellow to light yellow (towards green) when $\mathrm{h}^{\mathrm{o}}$ values was increased as $\beta C D$ addition also was increased. Whereas $\mathrm{C}^{*}$ values of egg yolk powder showed that as egg yolk pigment concentrations reduced, the $\mathrm{C}^{*}$ values lessened.

The yellow-orange colour of yolk is due to carotenoid pigments, primarily xanthophylls with minor amount of carotene [31]. Awad et al. [27] reported that $\beta$-carotene concentrations of egg yolk powder treatment with $\beta$-CD were lower than those of untreated egg yolk powder. Except for problems with colour, these results suggest that CD can be used to produce a low cholesterol egg product with functional properties similar to those of the original liquid egg yolk.

\section{Conclusion}

Cholesterol has been successfully reduced from egg yolk using $\beta$-CD with minimal depletion of nutritional composition of egg yolk powder. Utilization of cholesterol-reduced egg yolk powder in food can be beneficial to food industry in production of healthy and nutritious products even minimizing the cost of loss in industry due to spoilage and improper handling of native egg yolk.

\section{Acknowledgement}

The authors would like to thank the Universiti Teknologi MARA, Shah Alam Malaysia for the financial support.

\section{References}

1. Li-Chan, E. C. Y., Powrie, W. D. and Nakai, S. (1995). The chemistry of eggs and egg products. In W. J. Stadelman \& O. J. Cotterill (Eds.), Egg science and technology. New York: Food Products Press, pp: $105-$ 175.

2. Laca, A., Sáenz, M. C., Paredes, B. and Díaz, M. (2010). Rheological properties, stability and sensory evaluation of low-cholesterol mayonnaises prepared using egg yolk granules as emulsifying agent. Journal of Food Engineering, 97: $243-252$.

3. Santos, C. D., Buera, M. P. and Mazzobre, M. F. (2011). Phase solubility studies and stability of cholesterol/ $\beta$ cyclodextrin inclusion complexes. Journal of Science Food and Agriculture, 91: 2551 -2557.

4. Han, E. M., Kim, S. H., Ahn, J. and Kwak, H. S. (2008). Comparison of cholesterol reduced cream cheese manufactured using crosslinked b-cyclodextrin to regular cream cheese. Asian-Australasian Journal of Animal Sciences, 21(1): $131-137$.

5. Han, E.-M., Kim, S.-H., Ahn, J. and Kwak, H.-S. (2005). Cholesterol removal from homogenized milk with crosslinked $\beta$-cyclodextrin by adipic acid. Asian-Australasian Journal of Animal Sciences, 18 (12): $1794-$ 1799.

6. Heshmati, A., and Khodadadi, I. (2009). Reduction of cholesterol in beef suet using lecithin. Journal of Food Composition and Analysis 22: 684 - 688.

7. Hettinga, D., (2005). Butter. In: Shahedi, F. (Ed.), Edible oil and fat products: Edible oils. $6^{\text {th }}$ ed. Bailey's industrial oil and fat products, John Wiley and Sons, Inc., New York, pp. 15 - 17.

8. Zeidler, G. (1995). Method for removal of cholesterol and fat from liquid egg yolk with recovery of free cholesterol as a by-product. US PATENT 5, 468511.

9. Zaibunnisa, A. H., Saim, N., Said, Ilias, R., Wan, A. and Hassan. (2009). Characterisation of cyclodextrin complexes with turmeric oleoresin. Journal of Food Chemistry, 114: 459 - 465.

10. Frazier, W. C. and Westhoff, D. C. (1988). Food Microbiology. $2^{\text {nd }}$ ed. McGraw- Hill Publisher Inc., New Delhi, India.

11. Awad, A. C. and Smith, D. M. (1996). Method for reduction of cholesterol in egg materials. US International Patent, 5, 484, 624.

12. Association of official analytical chemists (AOAC), Official methods of analysis. (1975). Washington, DC.

13. Association of official analytical chemists (AOAC), official methods of analysis. (1990). $15^{\text {th }}$ ed. Association of official analytical chemists, Arlington, VA. 
14. Kim, S. H., Ahn, J. and Kwak, H. S. (2004). Crosslinking of $\beta$-Cyclodextrin on cholesterol removal from milk. Archives of Pharmacal Research, 27 (11): 1183 - 1187.

15. Zaibunnisa, A. H., Noarashikin, S., Mamot, S. and Osman, H. (2009) .An experimental design approach for the extraction of volatile compounds from turmeric leaves (Curcuma domestica) using pressurized liquid extraction (PLE), Journal of Food Science and Technology, 42: 233-238.

16. Zara, R. F., Bonafé, E. G., Martin, C. A., Souza, N. E. D., Muniz, E. C. and Visentainer, J. V. (2012). American Journal of Analytical Chemistry, 3: 288 - 294.

17. Wang, Y., Sunwoo, H., Cherian, G. and Sim, J. S. (2000). Fatty acid determination in chicken egg yolk: A comparison of different methods. Poultry Science Journal, 79:1168 - 1171.

18. Meynier, A., Leborgne, C., Viau, M., Schuck, P., Guichardant, M., Rannou, C. and Anton, M. (2014). n-3 fatty acid enriched eggs and production of egg yolk powders: An increased risk of lipid oxidation?. Food Chemistry, 153: $94-100$.

19. Chen, C. (2003). Evaluation of air oven moisture content determination methods for rough rice. Biosystems Engineering Journal, 86(4): 447 - 457.

20. All'egre, P., Moulin, B., Gleize, G., Pieroni, F. and Charbit. (2006). Cholesterol removal by nanofiltration: Applications in nutraceutics and nutritional supplements. Journal of Membrane Science, 269:109 - 117.

21. Anton, M. (2007). Composition and structure of hen egg yolk. In R. Huopalahti, R. López-Fandiňo, M. Anton, \& R. Schade (Eds.), Bioactive egg compounds, Springer, pp. 1- 6.

22. Fauziah, C. I., Zaibunnisa, A. H. Osman, H. and Wan, A. W. M. (2013). Thermal analysis and surface morphology study of cholesterol:B-cyclodextrin inclusion complex. Advanced Materials Research, 812: 221 225.

23. McCully, K. A., Mok, C. C. and Common, R. H. (1962). Paper electrophoresis characterization of proteins and lipoproteins of hen's yolk. Canadian Journal of Biochemistry and Physiology, 40: 937 -952.

24. Kim, S-H., Han, E-M., Ahn, J. and Kwak, H-S. (2005). Effect of crosslinked-cyclodextrin on quality of cholesterol-reduced cream cheese. Asian-Australasian Journal of Animal Sciences 18(4): 584 - 589.

25. Ha, H. J., Jeon, S. S., Chang, Y. H., and Kwak, H. S. (2009). Entrapment of milk nutrients during cholesterol removal from milk by crosslinked $\beta$-cyclodextrin. Korean Journal for Food Science of Animal Resources, 29(5): $566-572$.

26. Williams, R. O., Mahaguna, V. and Sriwongjanya, M. (1998). Characterization of an inclusion complex of cholesterol and hydroxypropyl- $\beta$-cyclodextrin. European Journal of Pharmaceutics and Biopharmaceutics. 46: $355-360$.

27. Awad, A. C., Bennink, M. R., and Smith, D. M. (1997). Composition and functional properties of cholesterol reduced egg yolk. Poultry Science Journal, 76: $649-653$.

28. Smith, D. M., Awad, A. C., Bennink, M. R. and Gill, J. L. (1995). Cholesterol reduction in liquid egg yolk using $\beta$-cyclodextrin. Journal of Food Science, 60(4): 691 - 694.

29. Ha, H. J., Lee, J. E., Chang, Y. H. and Kwak, H-S. (2010). Entrapment of nutrients during cholesterol removal from cream by crosslinked $\beta$-cyclodextrin. International Journal of Dairy Technology, 63(1): $119-126$.

30. Kwak, H. S., Jung, C. S., Shim, S. Y. and Ahn, J. (2002). Removal of cholesterol from cheddar cheese by $\beta$ cyclodextrin. Journal of Agricultural and Food Chemistry, 50(25): 7293 - 7298.

31. Maskooki, A. M., Beheshti, S. H. R., Valibeigi, S. and Feizi, J. (2013). Effect of cholesterol removal processing using $\beta$-cyclodextrin on main components of milk. International Journal of Food Science, 2013: 1 - 6.

32. Li-Chan, E. C. Y. and Kim, H. O. (2008). Structure and chemical composition of eggs. In Y. Mine (Ed.), Egg bioscience and biotechnology, New Jersey: John Wiley \& Sons Inc., pp. 1 - 96.

33. Bianchi, M., Petracci, M. and Cavani, C. (2006). Processing, products and food safety. The influence of genotype, market live weight, transportation, and holding conditions prior to slaughter on broiler breast meat colour. Poultry Science, 85:123 - 128.

34. Wrolstada, R. E., Dursta R. W. and Lee, J. (2005). Tracking colour and pigment changes in anthocyanin products. Trends in Food Science \& Technology, 16: 423 - 428. 